\title{
Integrated Fixed Film Activated Sludge (IFAS) membrane BioReactor: The influence of the operational parameters
}

\author{
Giorgio Mannina ${ }^{\mathrm{a}, \mathrm{b}, *}$, Marco Capodici ${ }^{\mathrm{a}}$, Alida Cosenza ${ }^{\mathrm{a}}$, Daniele Di Trapani ${ }^{\mathrm{a}}$, Zhengyu Zhu ${ }^{\mathrm{b}}$, Yongmei Li ${ }^{\mathrm{b}}$ \\ ${ }^{a}$ Engineering Department, Palermo University, Viale delle Scienze, Ed. 8, 90128 Palermo, Italy \\ ${ }^{\mathrm{b}}$ College of Environmental Science and Engineering, Tongii University, 1239 Siping Road, Yangpu District, Shanghai 200092, China
}

\section{A R T I C LE IN F O}

\section{Keywords}

Biological nutrient removal

Membrane bioreactor

IFAS

Membrane fouling

Respirometry

\begin{abstract}
A B S T R A C T
The present paper investigated an Integrated Fixed Film Activated Sludge (IFAS) Membrane BioReactor (MBR) system monitored for 340 days. In particular, the short-term effects of some operational parameters variation was evaluated. Results showed a decrease of the removal rates under low $\mathrm{C} / \mathrm{N}$ values. Respirometry results highlighted that activated sludge was more active in the organic carbon removal. Conversely, biofilm has a key role during nitrification. The major fouling mechanism was represented by the cake deposition (irreversible).
\end{abstract}

\section{Introduction}

In the last years, the growing urbanization coupled to industrial activities promoted a huge rise of water resources demand and deterioration, making water treatment a global issue (Martín-Pascual et al., 2015). Biological treatment was recognized as cost-effective and more acceptable compared to chemical treatment from the environmental point of view (Mulkerrins et al., 2004). Nitrogen (N) and phosphorus (P) compounds (nutrients) represent a severe threat for the aquatic compartments mainly due to eutrophication, thus being a serious threat for environmental health and safe water supply. With this regards, the conventional activated sludge (CAS) process have improved with the biological nutrient removal (BNR) processes. Compared to the chemical nutrients removal, BNR treatments avoids chemical addition and the consequent production of chemical sludge, difficult to manage compared to the biological sludge (among others, Mannina et al., 2016a,b). Nutrients removal in such systems can be obtained by means of diverse in series conditions (i.e., anaerobic, anoxic and aerobic) (Ekama et al., 1983; Xu et al., 2014; Asadi et al., 2016). The biological $\mathrm{N}$ removal can be obtained by means of a two-step process: the first one being the ammonia oxidation to nitrites and nitrates achieved by autotrophic bacteria under aerobic conditions (nitrification); the second one is the reductive process of nitrates under anoxic conditions carried out by heterotrophic bacteria (heterotrophic denitrification) (Xu et al., 2014). P can be biologically removed by the growth under alternate anaerobic/aerobic conditions of polyphosphate-accumulating organisms (PAOs), able to store polyhydroxyalkanoates (PHAs) and or- thophosphate. On the other hand, with dissolved oxygen availability PAO bacteria are able to grow through PHA exploitation, storing intracellular polyphosphate (Naessens et al., 2012).

The of the sludge produced during BNR can have poor features in terms of settleability (Ekama et al., 1996; Wanner, 2002). Therefore, new technical solutions were introduced, such as coupling the BNR scheme with a membrane bioreactor (MBR) (Mannina et al., 2016a), for improving the behavior of BNR configurations.

MBRs feature excellent effluent quality characterized by very low suspended solid concentrations, enabling an almost complete TSS removal from the effluent, being an optimal way for overloaded wastewater treatment plants (WWTPs) (Mannina and Viviani, 2009). MBRs can be highly loaded and higher sludge retention time (SRT) can be maintained, with moderate production of excess sludge (Ramphao et al., 2005; Fu et al., 2009; Ersu et al., 2010). The moving bed biofilm reactors (MBBRs) involve carriers in movement in the whole reactor volume, enhancing the growth of biofilm (Ødegaard, 2006). Moreover, in MBBR-based Integrated Fixed Film Activated Sludge (IFAS) processes the bacteria grows simultaneously as suspended and attached biomass (Mannina et al., 2011; Leyva-Díaz et al., 2016a,b). The high retention time typical of biofilm promotes the growth of autotrophic species, able to sustain complete nitrification throughout the year.

Due to the advantages of both MBR and MBBR systems, very recently their combination was proposed in view of improving their behavior. The latter configuration is usually named moving bed MBR (MB-MBR), biofilm MBR (BF- MBR) or IFAS-MBR (Sun et al., 2012;

\footnotetext{
* Corresponding author at: Engineering Department, Palermo University, Viale delle Scienze, Ed. 8, 90128 Palermo, Italy.

E-mail address: giorgio.mannina@unipa.it (G. Mannina)
} 
Yang et al., 2012; Leyva-Díaz et al., 2013; Mannina et al., 2018b; Yang et al., 2014). However, due to the very recent implementation of these systems the studies reported in the literature are still limited. Indeed, there is a knowledge gap towards the effect of different operational variables, concerning the removal performances, biomass activity features and membrane fouling tendency. In this light, respirometry might represent a suitable tool for the characterization of the biokinetic/ stoichiometric parameters of both the involved biomasses (Leyva-Díaz et al., 2013). In particular, Leyva-Díaz et al. (2015) carried out a kinetic study comparing a biofilm MBR system with a MBR one and observed a higher concentration of nitrifying bacteria in the hybrid system (195.49 $\mathrm{mg} \mathrm{L}^{-1}$ ) compared to that of the conventional MBR $(86.56 \mathrm{mg}$ $\mathrm{L}^{-1}$ ), supporting the fact that the nitrifying activity might be higher in a hybrid system. In general, the performance of such hybrid system is strongly related to the imposed operational condition. Previous studies highlighted that the mixed liquor SRT might exert a key role on the performance of a complex system conceived for nutrients removal and characterized by the coexistence of activated sludge and biofilm. SRT higher than 8 days is required to perform nitrification, working with MBR it is possible to operate at higher SRT values thus reducing the sludge production, also improving nitrification process. In contrast, under shorter SRT external energy usage can be reduced while also maximizing the excess sludge production for biogas production ( $\mathrm{Fu}$ et al., 2017). Moreover, the carbon-to-nitrogen (C/N) ratio can influence functional microorganisms, including autotrophic, as ammonia oxidizing bacteria ( $\mathrm{AOB}$ ) and nitrite oxidizing bacteria (NOB), as well as heterotrophic species (Fu et al., 2009). Furthermore, it has been demonstrated that $\mathrm{C} / \mathrm{N}$ significantly influences the biological $\mathrm{P}$ removal (C/ $\mathrm{N} \leq 6$ favors the P releasing in the final settling) (Chen et al., 2015). Finally, the hydraulic retention time (HRT) can modify the features of mixed liquor, including the extracellular polymeric substances (EPS) and sludge stability (Xu et al., 2014; Deng et al., 2016; Nuansawan et al., 2016). Previous investigations demonstrated that at short HRT, corresponding to high organic loading rate (OLR) might increase the sludge viscosity also promoting the growth of filamentous types (Deng et al., 2016). Moreover, according to Deng and co-workers the OLR increase promoted the increase of growth rate and consequently the increase of the mixed liquor volatile suspended solid to mixed liquor total suspended solid (MLVSS/MLTSS) ratio, thus influencing the excess sludge stability.

In this light, the objective of the present paper was to provide an insight about the influence of different operational parameters in the short term on an IFAS-MBR plant conceived for BNR according to a University of Cape Town (UCT) scheme. Specifically, the influence on plant stability of rapid and relatively short-term changes in these operational parameters was investigated. Respirometric tests have been performed to highlight the different contribution of both biomasses on the system performances when changing the operational conditions. During 340 days of operation, the UCT-IFAS-MBR system was surveyed for carbon, $\mathrm{N}$ and $P$ removal, suspended biomass and biofilm activity and membrane filtration properties.

\section{Materials and methods}

\subsection{The plant description}

The IFAS-MBR pilot plant layout was realized as a UCT scheme (Ekama et al., 1983; Mannina et al., 2016a). The filtration stage was accomplished by means of an hollow fiber membrane (courtesy of Koch Membrane Systems Inc.; net surface area: $1.4 \mathrm{~m}^{2}$, porosity: $0.03 \mu \mathrm{m}$; material: proprietary polyvinylidene fluoride - PVDF) inserted within the MBR tank.

The membrane filtration cycle was carried out as follow. Suction was operated in continuous for $9 \mathrm{~min}$ with a constant flow rate $\left(\mathrm{Q}_{\mathrm{SUC}}\right)$.
In order to mitigate membrane fouling a backwashing flow rate $\mathrm{Q}_{\mathrm{BW}}$ (about $1.5 \mathrm{Q}_{\mathrm{suc}}$ ) was recycled through the membrane, by pumping back a fraction of permeate from the Clean-In-Place (CIP) tank. The net flow rate resulting by $9 \mathrm{~min}$ of suction and $1 \mathrm{~min}$ of backwashing was the inlet flow rate $\mathrm{Q}_{\mathrm{IN}}$. Return activated sludge $\left(\mathrm{Q}_{\mathrm{RAS}}\right)$ consisted in a flow rate equal to $4 \mathrm{Q}_{\mathrm{IN}}$ from MBR to the anoxic reactor. In order to maintain negligible the dissolved oxygen (DO) concentration inside the anoxic reactor, an oxygen depletion reactor (ODR) was interposed between the MBR and the anoxic reactor. Two other returned flow rates, $Q_{R 1}$ (equal to $\mathrm{Q}_{\mathrm{IN}}$ ) from the anoxic to the anaerobic reactor and $\mathrm{Q}_{\mathrm{R} 2}\left(5\right.$ times $\left.\mathrm{Q}_{\mathrm{IN}}\right)$ from the aerobic to the MBR compartment were also present. Sludge wasting operations were carried out from the aerobic reactor and the sludge waste flow rate $\left(Q_{W A S}\right)$ was changed depending on the operational conditions of each experimental cycle.

The plastic carriers $\left(0.95 \mathrm{~g} \mathrm{~cm}^{-3}\right.$ density and $500 \mathrm{~m}^{2} \mathrm{~m}^{-3}$ specific surface - Amitec Co.Ltd) were inserted in aerobic and anoxic reactors. The filling faction was 15\% (net surface area: $75 \mathrm{~m}^{2} \mathrm{~m}^{-3}$ ) and $40 \%$ (net surface area: $200 \mathrm{~m}^{2} \mathrm{~m}^{-3}$ ), anoxic and aerobic bioreactor, respectively.

The inlet wastewater was a blend of real (collected at the sewer system of the University Campus) and synthetic wastewater. The latter was a solution composed of sodium acetate $\left(\mathrm{CH}_{3} \mathrm{COONa}\right)$, glycerol $\left(\mathrm{C}_{3} \mathrm{H}_{8} \mathrm{O}_{3}\right)$ and dipotassium hydrogen phosphate $\left(\mathrm{K}_{2} \mathrm{HPO}_{4}\right)$. Acetate and glycerol represented $30 \%$ and $70 \%$ of the added COD in the synthetic wastewater. The synthetic wastewater was added with the aim to control the $\mathrm{C} / \mathrm{N}$ ratio of the feeding wastewater, depending on the experimental needs. Further information about wastewater can be found in literature (Mannina et al., 2018a).

\subsection{Experimental campaigns and operational conditions}

In the present experimental campaign, nine operational cycles were investigated relating to the variation of SRT (Phase I), C/N ratio (Phase II) and HRT-SRT (Phase III), as reported in Table 1.

During each phase, the influence on plant stability of rapid and relatively short-term changes in the operational conditions was investigated. Different cycles were considered for each phase. Specifically, in Phase I (cycle 1-3) the influence of SRT variation was assessed. During Phase II (cycle 4-6) it was analyzed the effect that the $\mathrm{C} / \mathrm{N}$ change had on the system behavior. Finally, during Phase III (cycle 7-9) the influence of simultaneous HRT-SRT variations on the system behavior was analyzed.

Table 1

Operational conditions throughout experiments.

\begin{tabular}{|c|c|c|c|c|c|c|}
\hline \multirow[t]{2}{*}{ Phase } & \multirow[t]{2}{*}{ Cycle } & \multicolumn{5}{|c|}{ Operational parameters } \\
\hline & & Duration & SRT & $\mathrm{C} / \mathrm{N}$ & HRT & $\mathrm{Q}_{\mathrm{IN}}$ \\
\hline & & [d] & [d] & {$[-]$} & {$[\mathrm{h}]$} & $\begin{array}{l}{[\mathrm{L}} \\
\left.\mathrm{h}^{-1}\right]\end{array}$ \\
\hline \multirow[t]{3}{*}{ I } & 1 & $1-66$ & $\infty$ & 8.5 & 30 & 20 \\
\hline & 2 & $67-95$ & 30 & & & \\
\hline & 3 & $103-134$ & 15 & & & \\
\hline \multirow[t]{3}{*}{ II } & 4 & 135-191 & 45 & 5 & 30 & 22 \\
\hline & 5 & $192-221$ & & 10 & & \\
\hline & 6 & $222-249$ & & 2 & & \\
\hline \multirow[t]{3}{*}{ III } & 7 & $250-282$ & 56 & 10 & 30 & 15 \\
\hline & 8 & $283-310$ & 31 & & 15 & 30 \\
\hline & 9 & $311-340$ & 7 & & 13 & 35 \\
\hline
\end{tabular}




\subsection{Analytical methods}

Throughout experiments the following chemical parameters were analyzed according to standard methods (APHA, 2005):

- total and volatile suspended solid (TSS, VSS);

- total chemical oxygen demand ( $\mathrm{COD}_{\mathrm{TOT}}$ ) and supernatant $\mathrm{COD}$ (COD ${ }_{\text {SUP }}$;

- ammonium nitrogen $\left(\mathrm{NH}_{4}-\mathrm{N}\right)$, nitrite nitrogen $\left(\mathrm{NO}_{2}-\mathrm{N}\right)$, nitrate nitrogen $\left(\mathrm{NO}_{3}-\mathrm{N}\right)$ and total nitrogen $(\mathrm{TN})$;

- phosphate $\left(\mathrm{PO}_{4}-\mathrm{P}\right)$ and total phosphorus (TP).

The free ammonia concentration $\left(\mathrm{FA}, \mathrm{NH}_{3}\right.$ ) was also estimated (Hansen et al., 1998).

The biofilm growth was assessed according to literature (Mannina et al., 2011; Di Trapani et al., 2008; 2010, 2018).

Concerning the COD removal, the biological efficiency $\left(\eta_{\text {BIO }}\right)$, total efficiency $\left(\eta_{\text {TOT }}\right)$ and physical efficiency ( $\left.\eta_{\text {PHYS }}\right)$ due to membrane filtration were estimated according to previous literature (Mannina et al., $2016 a, b)$. The nitrification $\left(\eta_{\text {nit }}\right)$, denitrification $\left(\eta_{\text {denit }}\right)$ and total nitrogen $\left(\eta_{\text {Ntot }}\right)$ efficiencies were assessed according to the expressions reported by Mannina et al. (2016a,b).

Respirometry was applied on both suspended and attached biomass samples (separately) in order to assess the kinetic and stoichiometric behavior of biomass. Biomass respirometry was assed according to literature (Mannina et al., 2016b; Di Trapani et al., 2008; 2018). Briefly, respirometry on suspended biomass samples was carried out by imposing a VSS concentration in the respirometer of $2-3 \mathrm{gVSS} \mathrm{L}^{-1}$ (eventually diluting the samples with permeate). The batch tests on biofilm were carried out with colonized carriers and permeate with the same filling fraction of the aerobic reactor $(40 \%)$ in the respirometer. The dissolved oxygen (DO) concentration was maintained in the range 3.5-5.5 $\mathrm{mg} \mathrm{O}_{2} \mathrm{~L}^{-1}$ for all batch tests. The samples were maintained at constant temperature of $20 \pm 1{ }^{\circ} \mathrm{C}$ by means of a thermostatic cryostat.

Extracellular polymeric substances (EPSs), dissolved (SMP, soluble microbial product) or bound to the floc matrix (EPS Bound $_{1}$ were evaluated according to previous studies (i.e., Mannina et al., 2016b).

Membrane fouling analysis was carried out by monitoring the total resistance to filtration $\left(\mathrm{R}_{\mathrm{T}}\right)$ as well as the single fouling mechanisms through the application of a resistance-in-series (RIS) model according to Mannina et al. (2016a). The normalized $\left(20^{\circ} \mathrm{C}\right)$ membrane permeability $\left(\mathrm{K}_{20}\right)$ was assessed through the expression reported by Robles et al. (2013).

The capillary suction time (CST) and the specific resistance to filtration (SRF) have been recognized as representative parameters for the assessment of sludge dewaterability (Capodici et al., 2016) and were evaluated in accordance with UNI EN 14701-1:2006 and UNI EN 14701-2:2006 for CST and SRF, respectively.

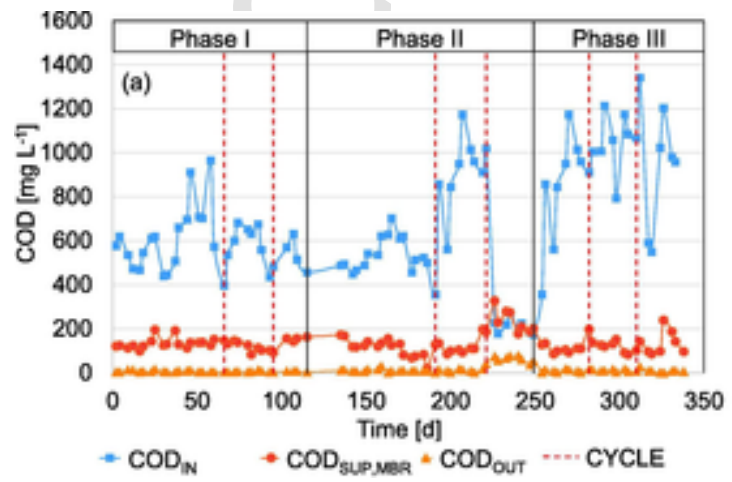

\section{Results and discussion}

\subsection{Treatment performance of the IFAS-UCT-MBR system}

\subsubsection{COD removal related to operational parameters}

The COD concentration profile as well as COD removal efficiency throughout the experimental campaign are reported in Fig. 1. Specifically, the COD removal efficiency is reported in terms of total ( $\eta_{\text {Tот }}$ ), biological ( $\left.\eta_{\mathrm{BIO}}\right)$ and physical removal, due to membrane filtration ( $\left.\eta_{\mathrm{PHYS}}\right)$.

The COD in the influent wastewater (real + synthetic) varied in the range $-1340 \mathrm{mg} \mathrm{L}^{-1}$ (Fig. 1a). The influent COD concentration fluctuation was due to the different amount of synthetic wastewater dosed during the operational phases.

The effluent COD ranged between $14 \mathrm{mg} \mathrm{L}^{-1}$ and $78 \mathrm{mg} \mathrm{L}^{-1}$ (Fig. 1a). The effluent Italian Standard limit for COD $\left(125 \mathrm{mg} \mathrm{L}^{-1}\right)$ has always been respected.

High COD removal efficiencies were achieved during Phase I (cycle $1-3)$. In particular, an average value of $77 \%$ and $99 \%$ was achieved for biological and total COD removal respectively. According to literature, the variation of SRT resulted to be irrelevant in terms of COD removal (Van den Broeck et al., 2012).

During Phase III (cycles 7-9), the highest value of $\eta_{\text {BIO }}$ and $\eta_{\text {TOт }}$ were obtained ( 86 and 99\%, respectively). This result might be due to the increased OLR, that promoted the biomass heterotrophic activity; moreover, in Phase III the $\mathrm{C} / \mathrm{N}$ ratio was close to 10 (average value), representing an optimal value for the organic carbon biological removal (Fu et al., 2009). Comparable findings were achieved by Duan et al. (2015). Duan and co-workers achieved a COD removal of $97 \%$ in a MBBR-MBR system under hybrid configuration (having 30\% of filling fraction and 17 h HRT). During Phase II (cycles 4-6) the COD lowest removal efficiencies were achieved (67 and 92\% for $\eta_{\text {BIO }}$ and $\eta_{\text {TOT }}$, respectively). As outlined in Section 3.2.2, this result was due to the fact that during cycle 6 the low $\mathrm{C} / \mathrm{N}$ value strongly affected the biomass biological activity (average $\eta_{\mathrm{BIO}}$ in cycle 6 equal to 23.5\%). Nevertheless, despite this poor biological performance, in cycle 6 the pilot plant provided a COD removal of $70 \%$.

\subsubsection{Nitrogen and phosphorus removal}

During experiments, the nitrification, denitrification as well as total nitrogen removal achieved in the pilot plant were significantly different (Fig. 2a and b). High nitrification performances were achieved throughout experiments. Leyva-Díaz et al. (2015) found also higher concentration of nitrifying bacteria in MBBR-MBR system compared to the MBR process. During cycle 6 the nitrification efficiency decreased. Indeed, during cycle 6 a nitrite accumulation occurred. The nitrite accumulation could be due to FA $\left(>0.5 \mathrm{mg} \mathrm{L}^{-1}\right)$. FA partially inhibited the NOB activity (Kim et al., 2006). The average ammonia removal in cycle 6 was $80 \%$.

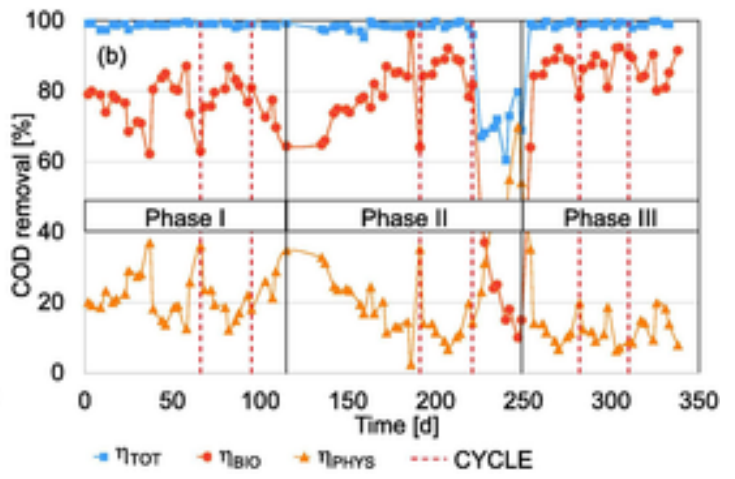

Fig. 1. Evolution of organic matter concentrations (a) and removal (b) throughout experiments. 

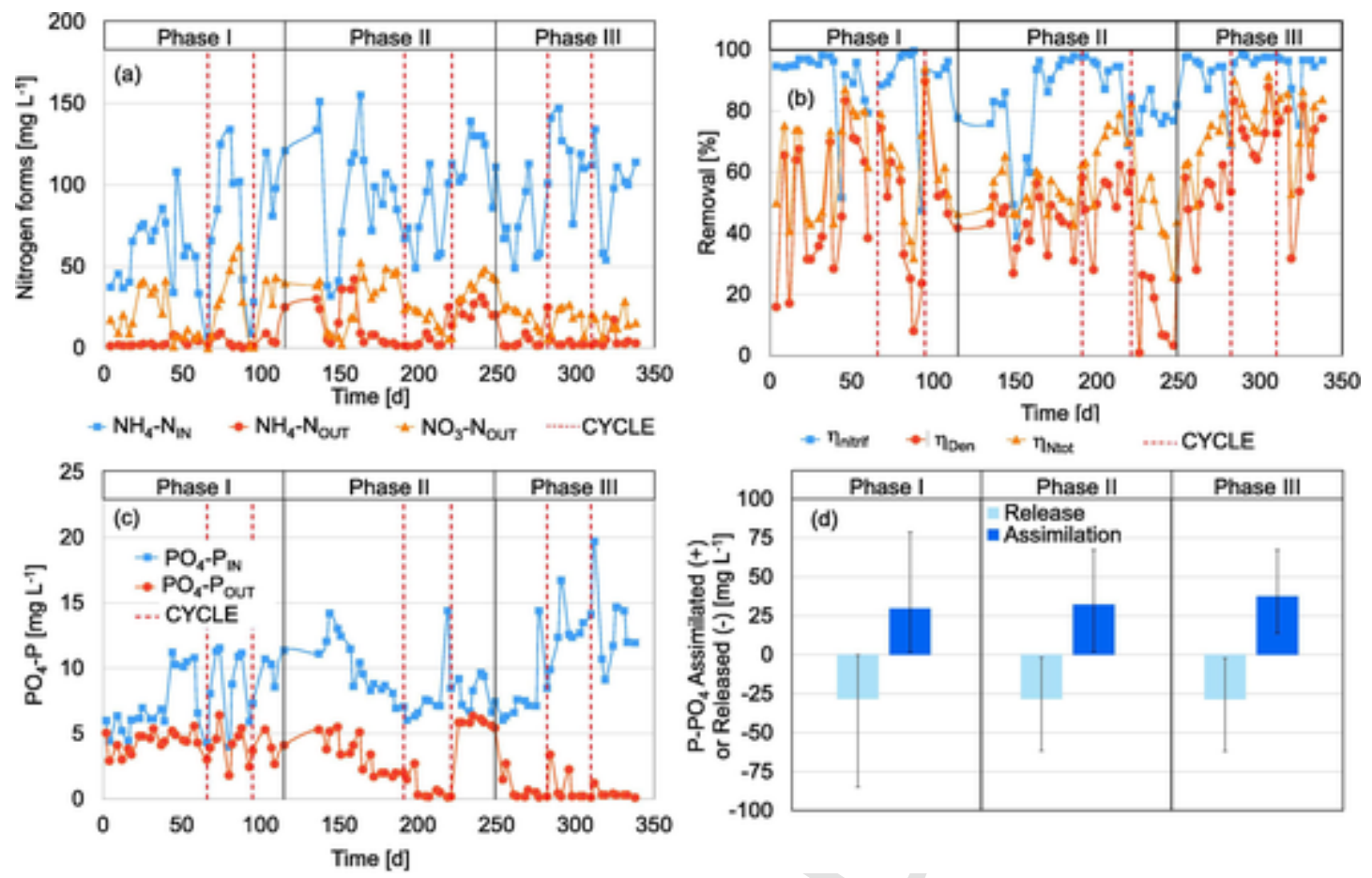

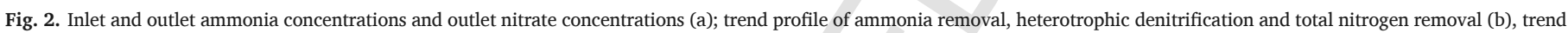
profile of inlet and outlet ortho-phosphate concentration (c) and average release/uptake (d) during experiments.

Nevertheless, excepting cycle 6 , the system enabled a huge nitrification efficiency. This result might be due to the attached biomass in the aerobic compartment, characterized by a long retention and being plentiful of autotrophic bacteria.

A different behavior was observed towards denitrification and nitrogen removal throughout experiments; the total nitrogen removal includes the nitrogen used for metabolic growth by bacteria. During Phase I, significant variations of total nitrogen removal rates were obtained. The low carbon availability during nitrification caused the previous result.

The lowest performance was achieved in the Phase II (cycles 4-6) operated at different $\mathrm{C} / \mathrm{N}$ ratios. Indeed, while during cycles 4 and 5 (characterized by $\mathrm{C} / \mathrm{N}$ ratio of 5 and $10 \mathrm{mgCOD} \mathrm{mg}^{-1} \mathrm{TN}$, respectively) an increasing trend of denitrification and nitrogen removal compared to the previous Phase I was observed, in cycle 6 (characterized by a $\mathrm{C} / \mathrm{N}$ ratio of $2 \mathrm{mgCOD} \mathrm{mg}^{-1} \mathrm{TN}$ ) there was an abrupt decrease of removal rates. The average removal rates in Cycle 6 were 14 and $44 \%$ for denitrification and total nitrogen, with minimum values of 3 and $25 \%$, respectively. This discrepancy might be related to nitrogen uptake due to metabolic growth. In contrast, the system performance increased significantly in Phase III (cycles 7 to 9), characterized by a HRT-SRT decrease. This operational condition, achieved by increasing the inlet flow rate, promoted an increase of the organic loading rate that, preventing carbon limitation, enhanced heterotrophic denitrification (Ge et al., 2015 ) and, as a consequence, the total nitrogen removal. The TN removal efficiencies in cycles 7-9 (average values) were 69.4, 81.4 and $77 \%$, respectively. The results observed in the present study in terms of nitrogen removal are greater compared to what reported in literature (Leyva-Díaz et al., 2015).

The achieved results highlighted a different effect of the operational parameters on biological P removal (Fig. 2c and d). Indeed, it was observed an increasing trend of the removal efficiency in the different phases. In Phase I, the highest SRT values, especially when the system worked without sludge withdrawals (i.e. under complete sludge retention), probably hampered the biological P removal mechanism. Never- theless, the results achieved in cycle 2 (SRT $=30 \mathrm{~d}$ ) were in agreement with those obtained by Khan et al. (2014) who achieved a $\mathrm{PO}_{4} \mathrm{P}$ removal efficiency of $59.50 \%$. A better performance was observed in Phase II (operated at different influent $\mathrm{C} / \mathrm{N}$ values) with removal efficiency down to $13 \%$. The achieved efficiency towards $\mathrm{PO}_{4}-\mathrm{P}$ removal might be related to the low carbon availability during cycle 6 for anaerobic uptake by PAOs and anoxic heterotrophic denitrification. Consequently, the denitrification limitation leads to an increased $\mathrm{NO}_{3}-\mathrm{N}$ mass recycled to the anaerobic compartment, disturbing the PAOs activity. In Phase III, huge biological efficiencies of P removal were achieved. The high OLR, characterized by high amount of readily biodegradable fraction of COD (synthetic wastewater) enhanced the high bio-P removal (Rey-Martínez et al., 2019). The results obtained in Phase III are in the range of literature. Indeed, Leyva-Díaz et al. (2016a,b) achieved $81.42 \pm 3.85 \%$ of TP removal in a MBBR-MBR system that worked with a 18 h HRT.

\subsection{Biomass properties}

\subsubsection{Trend profile of suspended biomass and biofilm}

Both suspended and attached biomass could have influenced the different removal efficiencies.

The amount of biofilm, in terms of concentration, was lower than the activated sludge one for most of the experimental phases (Fig. 3) due to the biomass (biofilm and suspended) competition for the available substrates. The concentration of the activated sludge was characterized by huge variations during experiments, mainly due the different operational conditions in the different cycles.

In Phase I (cycles 1-3), the MLSS was characterized by initial increase in cycle 1 , when no sludge withdrawals occurred (excepting the moderate amounts needed for analyses), while it remained quite stable in the cycle 2 (SRT $=30 \mathrm{~d}$ ) and significantly decreased in cycle 3 $($ SRT $=15 \mathrm{~d})$. In the subsequent Phases, the aim was to keep the MLSS almost constant and close to 4 gTSS L $^{-1}$; therefore, sludge wasting operations were carried out accordingly, thus affecting the SRT values. 

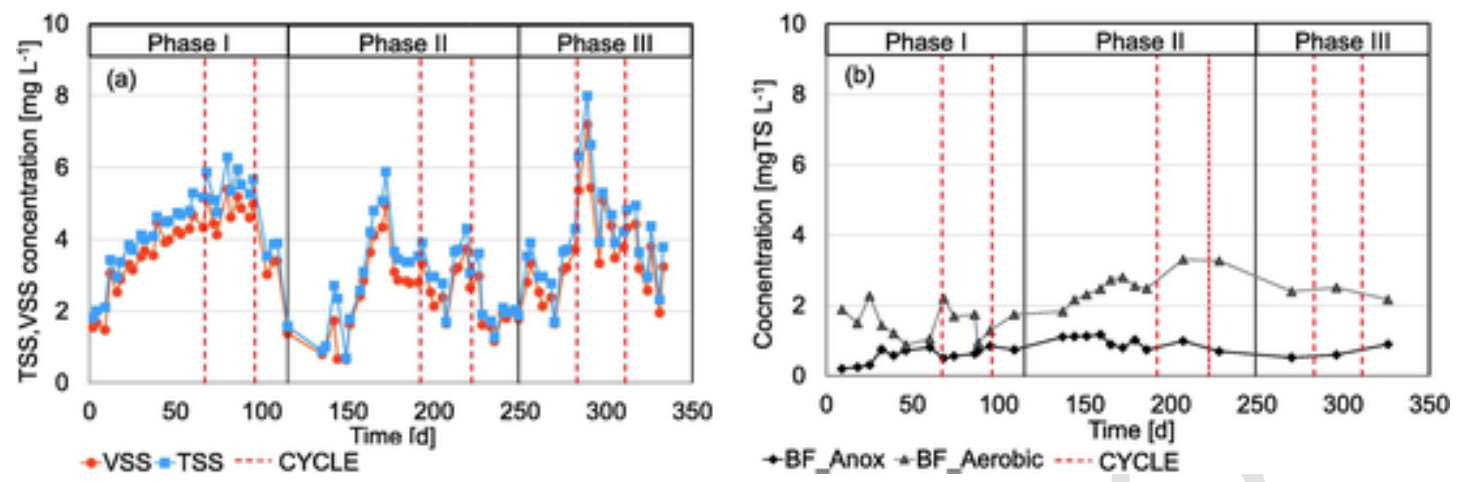

Fig. 3. Dynamics of TSS and VSS concentrations in mixed liquor (a) and TSS concentration in biofilm (b) in the different compartments in the experimental Phases.

Concerning the biofilm concentration, in the aerated compartment (BF_Aerobic) it was always higher compared to the anoxic one (BF_Anox). this finding might be due to a more suitable environment due to aerobic conditions. Indeed, aerobic metabolism is energetically favored with respect to anoxic metabolism; therefore, the biofilm growth resulted favored in the aerobic reactor yielding higher biofilm concentration.

\subsubsection{Biokinetic behavior related to operational conditions}

Respirometric batch tests highlighted the different kinetic behavior of the system, in terms of suspended and biofilm, depending on the operating conditions.

As an example, Fig. 4 shows the profile of maximum heterotrophic growth rate $\left(\mu_{\mathrm{H}, \max }\right)$ (considering the mixing of ordinary heterotrophs and PAOs) (Fig. 4a) and the maximum growth rate $\left(\mu_{\mathrm{A}, \max }\right)$ of autotrophs (considering both $\mathrm{AOB}$ and $\mathrm{NOB}$ ) during the overall experimental campaign (Fig. 4b). As general comment, it is possible to notice the different behavior showed by the two biomasses in terms of substrate removal. Indeed, suspended biomass showed higher affinity towards the organic carbon removal. The nitrification ability was similar for the two biomasses, with the growth rate of autotrophic species in the biofilm greater than that of activated sludge. This result could be due to the long retention time of biofilm that allowed the growth of an autotrophic population. Therefore, these findings suggested a biomass (suspended and biofilm) "specialization" towards the different substrates (Di Trapani et al., 2015), as highlighted by data reported in Table 2 .

Referring to the heterotrophic populations, the major impact was due to the lowest investigated $\mathrm{C} / \mathrm{N}$ in Phase II (cycle 6). The high decrease imposed to the $\mathrm{C} / \mathrm{N}$ ratio (equal to $2 \mathrm{mgCOD} \mathrm{mg}^{-1} \mathrm{TN}$ ), determined a carbon limitation, contributing to reduce the growth rate of heterotrophs for both biomasses.

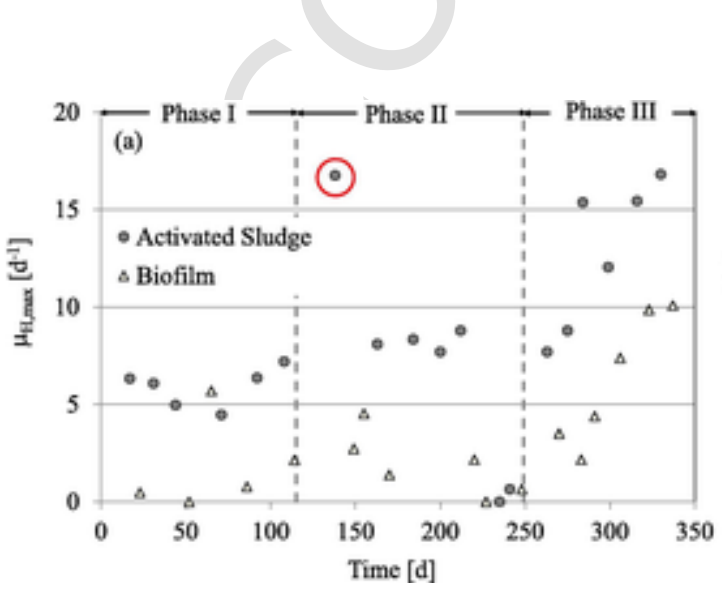

In contrast, an unlike behavior was noticed in Phase III (cycles 7-9): indeed, the organic loading rate increase promoted the growth of the heterotrophic organisms that reached significant values of the growth rate, referring in particular to the activated sludge. The simultaneous reduction of HRT and SRT promoted the increase of the active fraction of heterotrophic biomass. This result is corroborated by the values of the decay rate $b_{H}$ (which is an indicator of biomass activity), which highlighted high heterotrophic activity in Phase III, while the $\mathrm{C} / \mathrm{N}$ ratio (Phase II) revealed to be a potential stressing variable for biomass activity. The respiration rates (SOUR) showed a similar trend throughout experiments, thus confirming the role of decay rate as indicator of biomass activity.

Concerning autotrophic species, the maximum growth rates were reached in Phase III (cycles 7-9). The higher flow rates caused the rise of the ammonia loading rates, thus supplying the proper conditions to nitrifying population, enhancing the nitrification ability of the whole system, even for the activated sludge, despite the progressive SRT reduction in Phase III. This result, only apparently surprising, might be related to the "seeding" effect caused by biofilm detachment, which is rich of nitrifying species due to the high retention times; the biofilm released to the mixed liquor might have enhanced the nitrification ability of the mixed liquor. Even for the autotrophs, the worst performance was achieved in Phase II (cycle 6), when it as imposed a sharp decrease of the C/ $\mathrm{N}$ ratio, promoting an accumulation of free ammonia, thus causing inhibitory effects on the autotrophic organisms, referring in particular to NOB, which are very sensitive to free ammonia (Cydzik-Kwiatkowska et al., 2013).

\subsubsection{Sludge dewaterability}

In Fig. 5 the results of the dewaterability tests are reported. Overall, good dewaterability features were obtained throughout experiments, excepting Phase II (cycles 4-6), when a worsening of the system performance was achieved, especially in cycle 6 . Indeed, the abrupt C/

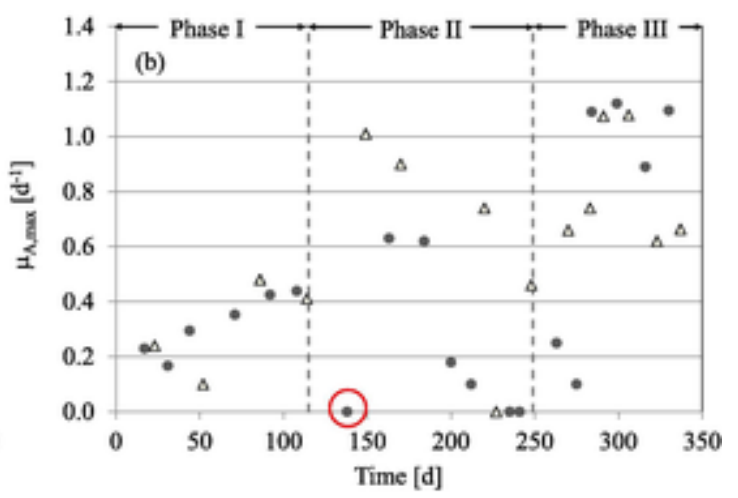

Fig. 4. Trend profile of $\mu_{\mathrm{H}, \max }$ (a) and $\mu_{\mathrm{A} \text {,max }}$ (b), referring to both activated sludge and biofilm. 
Table 2

Biokinetic parameters (average values) for activated sludge and biofilm, during the different Phases (standard deviation values are reported in brackets).

\begin{tabular}{|c|c|c|c|c|c|c|}
\hline & \multicolumn{2}{|l|}{$\begin{array}{l}\text { Phase I } \\
\text { (variable: SRT) }\end{array}$} & \multicolumn{2}{|l|}{$\begin{array}{l}\text { Phase II } \\
\text { (variable: } \mathrm{C} / \mathrm{N} \text { ) }\end{array}$} & \multicolumn{2}{|c|}{$\begin{array}{l}\text { Phase III } \\
\text { (variable: HRT-SRT) }\end{array}$} \\
\hline & $A S$ & Biofilm & $A S$ & Biofilm & $A S$ & Biofilm \\
\hline \multicolumn{7}{|l|}{ Heterotrophic } \\
\hline $\mathrm{Y}_{\mathrm{H}}\left[\mathrm{mgCOD} \mathrm{mg}^{-1} \mathrm{COD}\right]$ & $0.56( \pm 0.07)$ & $0.71( \pm 0.07)$ & $0.56( \pm 0.26)$ & $0.55( \pm 0.28)$ & $0.69( \pm 0.09)$ & $0.64( \pm 0.12)$ \\
\hline $\mathrm{Y}_{\mathrm{STO}}\left[\mathrm{mgCOD} \mathrm{mg}^{-1} \mathrm{COD}\right]$ & $0.70( \pm 0.05)$ & $0.79( \pm 0.01)$ & $0.66( \pm 0.30)$ & $0.68( \pm 0.34)$ & $0.82( \pm 0.05)$ & $0.83( \pm 0.06)$ \\
\hline$\mu \mathrm{H}, \max \left[\mathrm{d}^{-1}\right]$ & $5.90( \pm 1.00)$ & $1.13( \pm 0.89)$ & $7.19( \pm 5.64)$ & $1.73( \pm 1.31)$ & $12.69( \pm 3.80)$ & $6.23( \pm 3.37)$ \\
\hline $\mathrm{K}_{\mathrm{S}}\left[\mathrm{mgCOD} \mathrm{L}{ }^{-1}\right]$ & $5.45( \pm 1.03)$ & $3.94( \pm 1.01)$ & $7.12( \pm 8.42)$ & $4.25( \pm 2.37)$ & $23.75( \pm 22.95)$ & $6.34( \pm 1.47)$ \\
\hline $\mathrm{b}_{\mathrm{H}}\left[\mathrm{d}^{-1}\right]$ & $0.26( \pm 0.17)$ & $0.22( \pm 0.08)$ & $0.23( \pm 0.16)$ & $0.24( \pm 0.15)$ & $0.38( \pm 0.27)$ & $0.51( \pm 0.43)$ \\
\hline $\begin{array}{l}\text { SOUR }_{\max }\left[\mathrm{mgO}_{2} \mathrm{~g}^{-1} \mathrm{VSS} \mathrm{h}^{-1}\right] \\
\text { Autotrophic }\end{array}$ & $17.48( \pm 3.97)$ & $3.21( \pm 1.61)$ & $18.07( \pm 12.79)$ & $4.05( \pm 3.12)$ & $29.59( \pm 5.76)$ & $8.72( \pm 3.28)$ \\
\hline $\mathrm{Y}_{\mathrm{A}}\left[\mathrm{mgVSS}_{\mathrm{mg}}^{-1} \mathrm{~N}\right]$ & $0.21( \pm 0.06)$ & $0.39( \pm 0.15)$ & $0.29( \pm 0.23)$ & $0.50( \pm 0.19)$ & $0.33( \pm 0.14)$ & $0.45( \pm 0.19)$ \\
\hline$\mu \mathrm{A}, \max \left[\mathrm{d}^{-1}\right]$ & $0.32( \pm 0.11)$ & $0.31( \pm 0.17)$ & $0.31( \pm 0.30)$ & $0.75( \pm 0.21)$ & $0.76( \pm 0.46)$ & $0.81( \pm 0.21)$ \\
\hline $\mathrm{K}_{\mathrm{NH}}\left[\mathrm{mgNH}_{4}-\mathrm{N} \mathrm{L}^{-1}\right]$ & $2.47( \pm 2.77)$ & $0.79( \pm 0.34)$ & $1.92( \pm 1.54)$ & $1.24( \pm 0.95)$ & $6.32( \pm 7.72)$ & $0.43( \pm 0.27)$ \\
\hline Nitrif. Rate $\left[\mathrm{mgNH}_{4} \mathrm{~L}^{-1} \mathrm{~h}^{-1}\right]$ & $4.40( \pm 1.57)$ & $1.44( \pm 0.65)$ & $2.54( \pm 2.18)$ & $4.71( \pm 1.23)$ & $5.13( \pm 2.89)$ & $5.47( \pm 0.89)$ \\
\hline
\end{tabular}
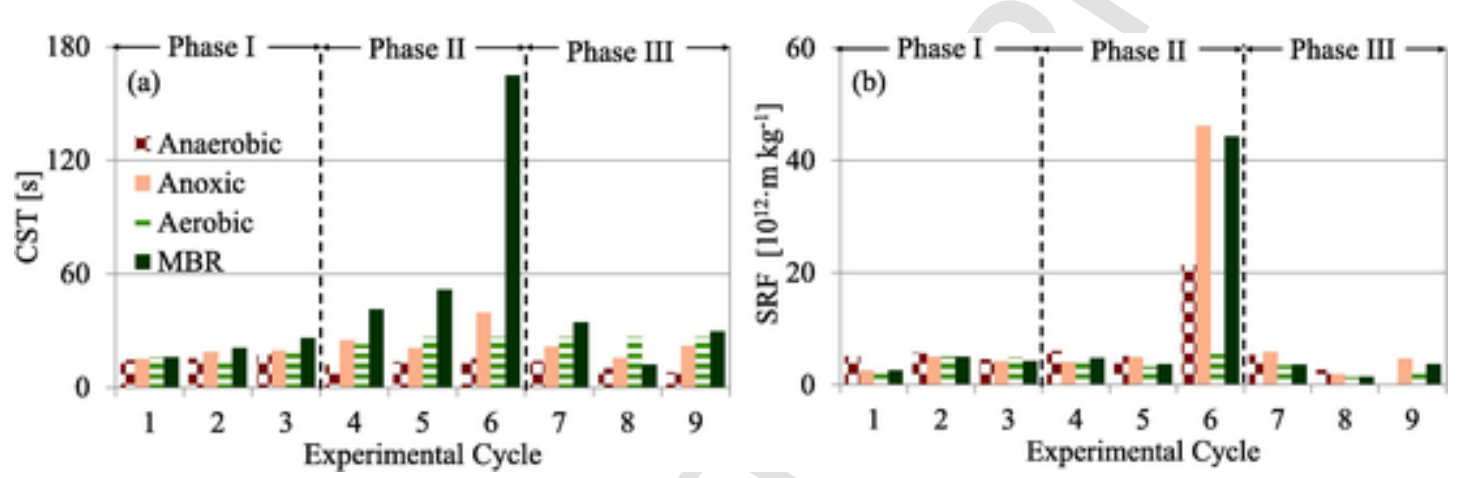

Fig. 5. CST (a) and SRF (b) in the different reactors during the whole experimental phases.

$\mathrm{N}$ reduction in cycle 6 a release of SMP and a significant increase of both CST and SRF values were achieved.

\subsection{Membrane fouling tendency related to operational conditions}

\subsubsection{Influence of operational conditions}

The pattern of total resistance $\left(R_{T}\right)$ as well as the specific resistances (average values) achieved through the application of the RIS model are depicted in Fig. 6. The trend profile shown in Fig. 6a reports the daily values of $R_{T}$. The highest $R_{T}$ value $\left(4610^{12} \mathrm{~m}^{-1}\right.$ ) was achieved in Phase I (Fig. 6a); however, in Phase II it was observed the highest average $R_{T}$ value $\left(10.3610^{12} \mathrm{~m}^{-1}\right)$. The highest $R_{T}$ value $\left(4610^{12} \mathrm{~m}^{-1}\right)$ achieved Phase I was a consequence of a malfunctioning of the permeate pump occurred at day 78. Data reported in Fig. 6a show an increases fouling tendency (in terms of fouling rate) during cycle 1 , when five cleaning operations were needed to keep the TMP below -0.6 bar. In contrast, in cycle 2 and cycle 3 a reduced number of membrane cleanings were required (four and one, respectively). The lower MLSS concentration (weighted average) in cycle 1 compared to cycle $2\left(4\right.$ gTSS L $^{-1}$ and 5.7 gTSS L $^{-1}$, respectively) could promote a decrease of the cake thickness, thus reducing its role in terms of fouling mitigation (dynamic membrane). Therefore, it was observed a fouling rate increase in cycle 1 . This result is in line with literature (i.e., Martín-Pascual et al., 2016) who derived a fouling rate increase with the MLSS decrease.

Regarding Phase II, data reported in Fig. 6a show a rapid tendency to membrane fouling. Such tendency was clear in cycle 4 and cycle 5 . As a consequence, the highest $R_{T}$ value (average: $10.3610^{12} \mathrm{~m}^{-1}$ ) and the highest number of required cleanings (12) took place in Phase II.
The specific $\mathrm{SMP}_{\mathrm{C}}$ increased (average value) in MBR during Phase II (despite the MLSS increase) could have promoted this result.

The lowest values of $R_{T}$ (on average $3.110^{12} \mathrm{~m}^{-1}$ ) were achieved during last phase, likely debited to the increased permeate flow rate, ranging from $25 \mathrm{~L} \mathrm{~h}^{-1}$ (cycle 7) to $37 \mathrm{~L} \mathrm{~h}^{-1}$ (cycle 8) and $41.5 \mathrm{~L} \mathrm{~h}^{-1}$ (cycle 9). Previous results highlighted that the permeate flow rate represents the factors mostly affecting the membrane fouling (Martín-Pascual et al., 2016; Mannina and Cosenza, 2013).

The specific resistance fractions (average values) achieved through the RIS model application are reported in Fig. 6b-d. The achieved results highlighted that the different fractions were stable in Phases I and III. It should be noted that for both Phase I and III the resistance of irreversible component of cake $\left(\mathrm{R}_{\mathrm{C}, \text { irr }}\right)$ was the highest one (97 and $92 \%$ for Phase I, and Phase III, respectively) (Fig. 6b and d). Moreover, a low percentage of pore blocking $\left(\mathrm{R}_{\mathrm{PB}}\right)$ was observed for both Phase I and III (around 3\%) (Fig. 6b, Fig. 6d). The reversible cake layer $\left(\mathrm{R}_{\mathrm{C}, \mathrm{rev}}\right)$ resistance was equal to 2.6 and $4.1 \%$, respectively for Phase I and Phase III. In contrast, the result achieved in Phase II showed a different trend (Fig. $6 c$ ). Indeed, the $R_{C, \text { irr }}$ represented the most important fouling fraction, its value decreased till to $80 \%$ (Fig. 6c). Furthermore, a significant $\mathrm{R}_{\mathrm{PB}}$ increase was achieved in Phase II, up to $13 \%$. Such a result suggested that the $\mathrm{C} / \mathrm{N}$ variation in Phase II determined the variation of the activated sludge features (e.g, increased production of SMPc) which have likely promoted an increase of membrane fouling due to pore blocking (Kurita et al., 2016).

\subsubsection{Extracellular polymeric substances}

The specific EPS concentrations achieved in Phase III outlined a significant variation compared to the other phases. This achievement was 


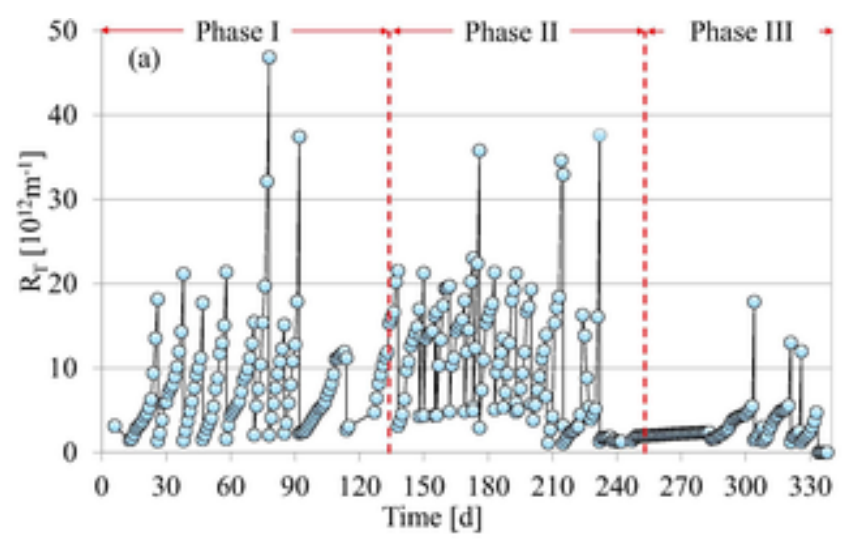

(b)

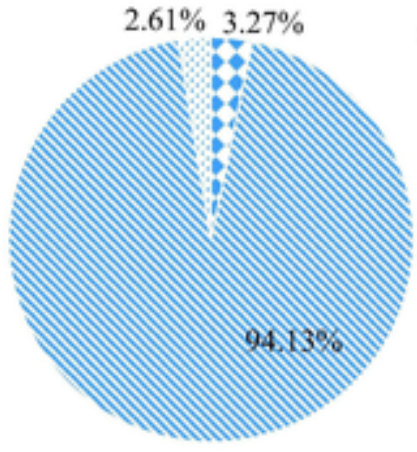

(c)

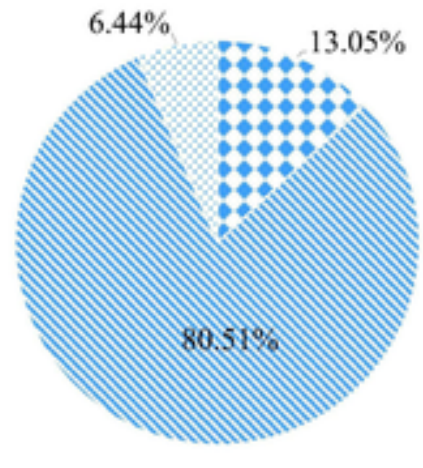

(d)

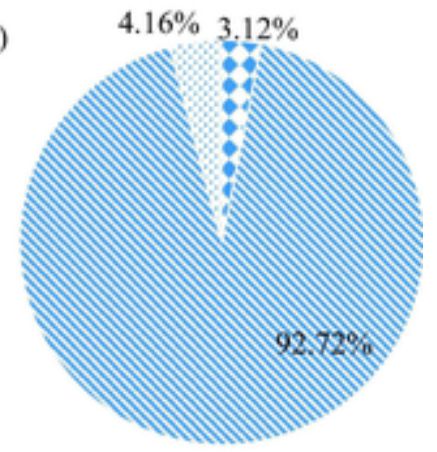

× RPB : RC,irr $\quad$ RC,rev

Fig. 6. Trend profile of $\mathrm{R}_{\mathrm{T}}$ (a) throughout experiments and average specific resistance fractions for Phase I (b), Phase II (c) and Phase III (d).

likely related to the joint result of the simultaneous variation of both HRT and SRT during Phase III. From the achieved results, the HRT was the parameter that mostly influenced the specific EPS in the anaerobic reactor (Phase III). The HRT change promoted a decrease of the protein fraction to $69 \mathrm{mg} \mathrm{g}^{-1}$ TSS in Phase III (average value in Phase I and II: $150 \mathrm{mg} \mathrm{g}^{-1}$ TSS). Moreover, the HRT variation promoted the rise of SMP $_{\mathrm{P}}$ from $31 \mathrm{mg} \mathrm{g}^{-1}$ TSS (average value in Phase I) to $72 \mathrm{mg} \mathrm{g}^{-1}$ TSS in Phase II and $135 \mathrm{mg} \mathrm{gTSS}^{-1}$ in Phase III. The significant SMP release might have been favored by the growth of PAO bacteria under low HRT values (Bitton, 2005).

The EPS concentration in the anoxic compartment was mainly affected by the $\mathrm{C} / \mathrm{N}$ variation (Phase II). An increase of all EPS fractions occurred in Phase II inside the anoxic reactor, referring in particular to the SMP fractions (both $\mathrm{SMP}_{\mathrm{P}}$ and $\mathrm{SMP}_{\mathrm{C}}$ ). Indeed, the specific $\mathrm{SMP}_{\mathrm{P}}$ concentration in the anoxic compartment raised on average from $7 \mathrm{mg} \mathrm{g}^{-1}$ TSS (Phase I) up to $56.5 \mathrm{mg} \mathrm{g}^{-1}$ TSS (Phase II). Conversely, the specific $\mathrm{SMP}_{\mathrm{C}}$ concentration raised from 1.7 (Phase I) to $13.5 \mathrm{mg} \mathrm{gTSS}^{-1}$ (Phase II). This achievement might be related to the strong effect exerted by $\mathrm{C} /$ $\mathrm{N}$ on the heterotrophic growth under anoxic conditions. When the $\mathrm{C} /$ $\mathrm{N}$ was decreased, significant sludge deflocculation phenomena occurred, thus promoting the rise of SMP in the bulk liquid, due to a carbon limitation (Ye et al., 2011).

The HRT revealed to be the most influential parameter towards EPS production also for the aerobic and MBR reactors. Nevertheless, contrarily to what observed in the anaerobic reactor, in both the aerobic and MBR compartments a simultaneous EPS $S_{P}$ increase and a $\mathrm{SMP}_{\mathrm{P}}$ decrease occurred during Phase III. This result, as demonstrated in previous literature, might be related to the increase of the average particle size enhanced by the high organic loading rate, which led to a higher bound EPS content (Chae et al., 2006).

Nevertheless, a $\mathrm{SMP}_{\mathrm{C}}$ increase was observed in the MBR compartment in Phase II (15.2 $\mathrm{mg} \mathrm{g}^{-1}$ TSS) compared to Phase I (5.5 $\mathrm{mg} \mathrm{g}^{-1}$
TSS). Therefore, it was demonstrated that the stress effect of $\mathrm{C} / \mathrm{N}$ change could have a significant consequence in terms of fouling. Indeed, Le-Clech et al. (2006) highlighted the effect of carbohydrate in SMP towards irreversible fouling mechanisms.

\section{Conclusions}

In light of the above results, the findings of the present study highlighted the robustness of the IFAS-UCT-MBR system for the investigated values of the operational variables. Nevertheless, the $\mathrm{C} / \mathrm{N}$ ratio confirmed to be a very stressful variable, affecting the removal efficiencies, the sludge dewaterability as well as membrane fouling which was characterized in Phase II by the highest irreversible fouling. In contrast, the simultaneous HRT-SRT decrease did not entail the worsening of the system performance: therefore, an IFAS-UCT-MBR system can be operated at low HRT-SRT values still sustaining excellent removal performance.

\section{Uncited references}

De la Torre et al. (2013), Leyva-Díaz et al. (2014), Rahimi et al. (2011), Yang et al. (2009).

\section{CRediT authorship contribution statement}

Giorgio Mannina: Conceptualization, Methodology, Supervision, Writing - review \& editing. Marco Capodici: Data curation, Writing original draft. Alida Cosenza: Data curation, Writing - original draft. Daniele Di Trapani: Data curation, Writing - original draft. Zhengyu Zhu: . Yongmei Li: .

\section{Declaration of Competing Interest}

The authors declare that they have no known competing financial interests or personal relationships that could have appeared to influence the work reported in this paper. 


\section{Appendix A. Supplementary data}

Supplementary data to this article can be found online at https://doi. org/10.1016/j.biortech.2020.122752.

\section{References}

APHA, 2005. Standard Methods for the Examination of Water and Wastewater. APHA, AWWA and WPCF, Washington DC, USA.

Asadi, A., Zinatizadeh, A.A., Van Loosdrecht, M., 2016. High rate simultaneous nutrients removal in a single air lift bioreactor with continuous feed and intermittent discharge regime: process optimization and effect of feed characteristics. Chem. Eng. J. 301, 200-209.

Bitton, G., 2005. Wastewater Microbiology. John Wiley \& Sons Inc., Hoboken, NJ.

Capodici, M., Mannina, G., Torregrossa, M., 2016. Waste activated sludge dewaterability: comparative evaluation of sludge derived from CAS and MBR systems. Desalin. Water Treat. 1-9. doi:10.1080/19443994.2016.1180478.

Chae, S.R., Ahn, Y.T., Kang, S.T., Shin, H.S., 2006. Mitigated membrane fouling in a vertical submerged membrane bioreactor (VSMBR). J. Membr. Sci. 280, 572-581.

Chen, Y., Li, B., Ye, L., Peng, Y., 2015. The combined effects of COD/N ratio and nitrate recycling ratio on nitrogen and phosphorus removal in anaerobic/anoxic/aerobic (A2/ O)-biological aerated filter (BAF) systems. Biochem. Eng. J. 93, 235-242.

Cydzik-Kwiatkowska, A., Zielin’ska, M., Bernat, K., Wojnowska-Baryła, I., Truchan, T., 2013. Treatment of high-ammonium anaerobic digester supernatant by aerobic granular sludge and ultrafiltration processes. Chemosphere 90, 2208-2215.

De la Torre, T., Rodríguez, C., Gómez, M.A., Alonso, E., Malfeito, J.J., 2013. The IFAS-MBR process: a compact combination of biofilm and MBR technology as RO pretreatment. Desalin. Water Treat. 51, 1063-1069.

Deng, L., Guo, W., Ngo, H.H., Du, B., Wei, Q., Tran, N.H., Nguyen, N.C., Chen, S.S., Li, L., 2016. Effects of hydraulic retention times and bioflocculant addition on membrane fouling in a sponge-submerged membrane bioreactor. Bioresour. Technol. 210, 11-17.

Di Trapani, D., Mannina, G., Torregrossa, M., Viviani, G., 2010. Quantification of kinetic parameters for heterotrophic bacteria via respirometry in a hybrid reactor. Water Sci. Technol. 61 (7), 1757-1766.

Di Trapani, D., Mannina, G., Torregrossa, M., Viviani, G., 2008. Hybrid moving bed biofilm reactors: A pilot plant experiment. Water Sci. Technol. 57 (10), 1539-1545.

Di Trapani, D., Di Bella, G., Mannina, G., Torregrossa, M., Viviani, G., 2015. Effect of C/ $\mathrm{N}$ shock variation on the performances of a moving bed membrane bioreactor. Bioresour. Technol. 189, 250-257.

Di Trapani, D., Viviani, G., Mannina, G., 2018. Membrane Bioreactors for wastewater reuse: respirometric assessment of biomass activity during a two year survey. J. Cleaner Prod. 202, 311-320.

Duan, L., Tian, Y., Liu, X., Song, Y., Yang, L., Zhang, J., 2015. Comparison between moving bed-membrane bioreactor and conventional membrane bioreactor systems. Part II: bacterial community. Environ. Earth Sci. 73, 4891-4902.

Ekama, G.A., Siebritz, I.P., Marais, G.R., 1983. Considerations in the process design of nutrient removal activated sludge processes. Wat. Sci. Tech. 15 (3-4), 283-318.

Ekama, G.A., Wentzel, M.C., Casey, T.G., Marais, G.R., 1996. Filamentous organism bulking in nutrient removal activated sludge. Paper 3: Stimulation of the selector effect under anoxic conditions. Water SA 22, 119-126.

Ersu, C.B., Ong, S.K., Arslankaya, E., Lee, Y.W., 2010. Impact of solids residence time on biological nutrient removal performance of membrane bioreactor. Water Res. 44, 3192-3202.

Fu, Z., Yang, F., Zhou, F., Xue, Y., 2009. Control of COD/N ratio for nutrient removal in a modified membrane bioreactor (MBR) treating high strength wastewater. Bioresour. Technol. 100, 136-141.

Fu, C., Yue, X., Shi, X., Ng, K.K., Ng, H.Y., 2017. Membrane fouling between a membrane bioreactor and a moving bed membrane bioreactor: Effects of solids retention time. Chem. Eng. J. 309, 397-408.

Ge, S., Wang, S., Yang, X., Qiu, S., Li, B., Peng, Y., 2015. Detection of nitrifiers and evaluation of partial nitrification for wastewater treatment: a review. Chemosphere 140, 85-98. doi:10.1016/j.chemosphere.2015.02.004.

Hansen, K.H., Angelidaki, I., Ahring, B.K., 1998. Anaerobic digestion of swine manure: inhibition by ammonia. Water Res. 32, 5-12.

Khan, S.J., Ahmad, A., Nawaz, M.S., Hankins, N.P., 2014. Membrane fouling and performance evaluation of conventional membrane bioreactor (MBR), moving biofilm MBR and oxic/anoxic MBR. Water Sci. Technol. 69, 1403-1409.

Kim, D.-J., Lee, D.I., Keller, J., 2006. Effect of temperature and free ammonia on nitrification and nitrite accumulation in landfill leachate and analysis of its nitrifying bacterial community by FISH. Bioresour. Technol. 97, 459-468.

Kurita, T., Mogi, T., Kimura, K., 2016. Influence of different biofilm carriers on the operation and membrane fouling of submerged membrane bioreactors. Sep. Purif. Technol. $169,43-49$.

Le-Clech, P., Chen, V., Fane, T.A.G., 2006. Fouling in membrane bioreactors used in wastewater treatment. J. Membr. Sci. 284, 17-53.

Leyva-Díaz, J.C., Calderón, K., Rodríguez, F.A., González-López, J., Hontoria, E., Poyatos, J.M., 2013. Comparative kinetic study between moving bed biofilm reactor-membrane bioreactor and membrane bioreactor systems and their influence on organic matter and nutrients removal. Biochem. Eng. J. 77, 28-40.
Leyva-Díaz, J.C., Martín-Pascual, J., Muñío, M.M., González-López, J., Hontoria, E., Poyatos, J.M., 2014. Comparative kinetics of hybrid and pure moving bed reactor-membrane bioreactors. Ecol. Eng. 70, 227-234.

Leyva-Díaz, J.C., González-Martínez, A., González-López, J., Muñío, M.M., Poyatos, J.M., 2015. Kinetic modeling and microbiological study of two-step nitrification in a membrane bioreactor and hybrid moving bed biofilm reactor-membrane bioreactor for wastewater treatment. Chem. Eng. J. 259, 692-702.

Leyva-Díaz, J.C., Martín-Pascual, J., Poyatos, J.M., 2016. Moving bed biofilm reactor to treat wastewater. Int. J. Environ. Sci. Technol. 1-30, DOI. doi:10.1007/ s13762-016-1169-y.

Leyva-Díaz, J.C., Muñío, M.M., González-López, J., Poyatos, J.M., 2016. Anaerobic/ anoxic/oxic configuration in hybrid moving bed biofilm reactor-membrane bioreactor for nutrient removal from municipal wastewater. Ecol. Eng. 91, 449-458.

Mannina, G., Viviani, G., 2009. Hybrid moving bed biofilm reactors: an effective solution for upgrading a large wastewater treatment plant. Water Sci. Technol. 60 (5), 1103-1116.

Mannina, G., Di Trapani, D., Viviani, G., Ødegaard, H., 2011. Modelling and dynamic simulation of hybrid moving bed biofilm reactors: model concepts and application to a pilot plant. Biochem. Eng. J. 56, 23-36.

Mannina, G., Cosenza, A., 2013. The fouling phenomenon in membrane bioreactors: assessment of different strategies for energy saving. J. Membr. Sci. 444, 332-344.

Mannina, G., Capodici, M., Cosenza, A., Di Trapani, D., 2016. Carbon and nutrient biolog ical removal in a University of Cape Town membrane bioreactor: analysis of a pilot plant operated under two different C/N ratios. Chem. Eng. J. 296, 289-299.

Mannina, G., Capodici, M., Cosenza, A., Di Trapani, D., Viviani, G., 2016. Sequential batch membrane bio-reactor for wastewater treatment: the effect of increased salinity. Bioresour. Technol. 209, 205-212.

Mannina, G., Capodici, M., Cosenza, A., Di Trapani, D., 2018. Nitrous oxide from integrated fixed-film activated sludge membrane bioreactor: assessing the influence of operational variables. Bioresour. Technol. 247, 1221-1227. doi:10.1016/ j.biortech.2017.09.083.

Mannina, G., Ekama, G., Capodici, M., Cosenza, A., Di Trapani, D., Ødegaard, H., van Loosdrechtd, M., 2018. Influence of carbon to nitrogen ratio on nitrous oxide emission in an Integrated Fixed Film Activated Sludge Membrane BioReactor plant. J. Cleaner Prod. 176, 1078-1090.

Martín-Pascual, J., Reboleiro-Rivas, P., López-López, C., Leyva-Díaz, J.C., Jover, M., Muñío, M.M., González-López, J., Poyatos, J.M., 2015. Effect of the filling ratio, MLSS, hydraulic retention time, and temperature on the behavior of the hybrid biomass in a hybrid moving bed membrane bioreactor plant to treat urban wastewater. J. Environ. Eng. 141 (7). 04015007(1-10).

Martín-Pascual, J., Reboleiro-Rivas, P., Muñio, M.M., González-López, J., Poyatos, J.M., 2016. Membrane fouling of a hybrid moving bed membrane bioreactor plant to treat real urban wastewater. Chem. Eng. Process. 104, 112-119.

Mulkerrins, D., Dobson, A.D.W., Colleran, B., 2004. Parameters affecting biological phosphate removal from wastewaters. Environ. Int. 30 (2), 249-259.

Nuansawan, N., Boonnorat, J., Chiemchaisri, W., Chiemchaisri, C., 2016. Effect of hydraulic retention time and sludge recirculation on greenhouse gas emission and related microbial communities in two-stage membrane bioreactor treating solid waste leachate. Bioresour. Technol. 210, 35-42.

Naessens, W., Maere, T., Nopens, I., 2012. Critical review of membrane bioreactor models - Part 1: Biokinetic and filtration models. Bioresour. Technol. 122, 95-106.

$\emptyset$ degaard, H., 2006. Innovations in wastewater treatment: the moving bed biofilm process. Water Sci. Technol. 53, 17-33.

Rahimi, Y., Torabian, A., Mehrdadi, N., Habibi-Rezaie, M., Pezeshk, H., Nabi-Bidhendi, G.R., 2011. Optimizing aeration rates for minimizing membrane fouling and its effect on sludge characteristics in a moving bed membrane bioreactor. J. Hazard. Mater. 186, 1097-1102.

Ramphao, M. Wentzel, M.C., Merritt, R., Ekama, G.A, Young, T., Buckley, C.A., 2005 Impact of membrane solideliquid separation on design of biological nutrient removal activated sludge systems. Biotechnol. Bioeng. 89 (6), 630-646.

Rey-Martínez, N., Badia-Fabregat, M., Guisasola, A., Baeza, J.A., 2019. Glutamate as sole carbon source for enhanced biological phosphorus removal. Sci. Tot. Environ. 657, 1398-1408. doi:10.1016/j.scitotenv.2018.12.064.

Robles, A., Ruano, M.V., Ribes, J., Ferrer, J., 2013. Factors that affect the permeability of commercial hollow-fibre membranes in a submerged anaerobic MBR (HF-SAnMBR) system. Water Res. 47, 1277-1288.

Sun, C., Leiknes, T., Fredriksen, R.H., Riviere, E., 2012. Comparison of membrane filtration performance between biofilm-MBR and activated sludge-MBR. Desalin. Water Treat. 48, 285-293.

Van den Broeck, R., Van Dierdonck, J., Nijskens, P., Dotremont, C., Krzeminski, P., van der Graaf, J.H.J.M., van Lier, J.B., Van Impe, J.F.M., Smets, I.Y., 2012. The influence of solids retention time on activated sludge bioflocculation and membrane fouling in a membrane bioreactor (MBR). J. Membr. Sci. 401-402, 48-55.

Wanner, J., 2002. Control of filamentous bulking in activated sludge. In: Bitton, G. (Ed.), Encyclopedia of Environmental Microbiology. John Wiley \& Sons Inc., New York USA, pp. 1306-1315.

Xu, S., Wu, D., Hu, Z., 2014. Impact of hydraulic retention time on organic and nutrient removal in a membrane coupled sequencing batch reactor. Water Res. 55, 12-20.

Yang, S., Yang, F., Fu, Z., Lei, R., 2009. Comparison between a moving bed membrane bioreactor and a conventional membrane bioreactor on organic carbon and nitrogen removal. Bioresour. Technol. 100, 2369-2374.

Yang, F., Wang, Y., Bick, A., Girlon, J., Brenner, A., Gillerman, L., Herzberg, M., Oron, G., 2012. Performance of different configurations of hybrid growth membrane bioreactor (HG-MBR) for treatment of mixed wastewater. Desalination 284, 261-268. 
Yang, W., Syed, W., Zhou, H., 2014. Comparative study on membrane fouling between membrane-coupled moving bed biofilm reactor and conventional membrane bioreactor for municipal wastewater treatment. Water Sci. Technol. 69, 1021-1027.
Ye, F., Ye, Y., Li, Y., 2011. Effect of $\mathrm{C} / \mathrm{N}$ ratio on extracellular polymeric substances (EPS) and physicochemical properties of activated sludge flocs. J. Hazard. Mater. 188, $37-43$. 